\title{
The Influence of Leadership and Motivation on Teacher Work Performance
}

\author{
Sustri Yanti $^{1 *}$, Yasir Arafat ${ }^{2}$, Achmad Wahidy $^{2}$ \\ ${ }^{1}$ MTs Negeri 1 Musi Banyuasin \\ ${ }^{2}$ Universitas PGRI Palembang \\ *Corresponding author. E-mail: sustri58@gmail.com
}

\begin{abstract}
The article was to determine the effect of principal leadership and teacher work motivation on teacher work performance at MTS Negeri 1 Musi Banyuasin. This research was quantitative. The researcher used random sampling technique of 43 teachers as sample research at MTS Negeri 1 Musi Banyuasin. Data collection techniques used questionnaires, interviews, observations and test. Data collection was carried out by distributing questionnaires using a 5-point Likert scale to measure 75 statement items. The analysis technique used was multiple linear regression analysis. The results showed that the first, leadership had a partial and insignificant effect on teacher's achievement. Secondly, that motivation was partially and significantly influences teacher achievement. Thirdly, the principal's leadership and teacher motivation simultaneously and significantly influenced teacher achievement
\end{abstract}

Keywords: Leadership, Teacher Achievement, Teacher Work Performance

\section{INTRODUCTION}

The development of the world of education is currently progressing rapidly so that teachers are required to be able to create students who can survive in the environment and the world of work, this is balanced with Soft Skills and Hard Skills that can be implemented in the real world of work. One of the problems that exist in the world of education is the low achievement of teachers, this can affect student achievement [1][2]. Therefore, to improve the quality of education, teachers are required to be able to improve their ability in teaching and in providing interesting material that is supported by teaching aids so that teachers will get feedback on the results of their teaching [3]. Many factors affect teacher work performance, for instance the education facility [4], the salary, a less supportive work environment, lack of work experience, and low teacher motivation and lack of ability [5].

Job performance is the result of work in quality and quantity achieved by a teacher in carrying out tasks according to the responsibilities assigned to the teacher. The results of a person's efforts are determined by the abilities of his personal characteristics and perceptions of his role in the job.

The increase in work performance of teachers in schools is also influenced by a conducive work environment which is supported by a good relationship between the principal and teachers and the presence of an adequate physical work environment.
The success of education in schools is largely determined by the success of the principal in managing the education personnel available at the school. The head of the school is one of the components of education that has an effect on improving teacher performance [6]. The principal is responsible for the implementation of educational activities, school administration, coaching other educational personnel, and the utilization and maintenance of facilities and infrastructure [7]. The leadership of the principal really determines the quality, without good leadership the quality improvement process cannot be carried out and realized [8]. Leadership is the ability to influence other parties, through communication either directly or indirectly with the intention of moving people to be understanding and willing to follow the leader's will. [9]

Rivai stated that the leadership function of the principal has no significant effect on work performance. This means that changes in leadership functions will not have a significant effect on teacher work performance. The results of the data analysis show that the leadership function has a negative but not significant effect on teacher work performance. This means that if the leadership function is improved, it will reduce work performance. [10]

One of the tough challenges for organizations is how to motivate employees to grow and be well nurtured. Motivation is a force that encourages someone to do an activity. In this case, 
motivation can affect a person's achievement in carrying out certain activities. If teachers have high work motivation, they will be motivated to try to improve their ability to implement and evaluate the applicable curriculum in schools / madrasahs in order to obtain maximum work results [11]

Hidayat et al's research states that there is a significant effect of work motivation on teacher work performance in SMA Negeri 08 Lubuklinggau City. [12] In addition, Fahmi and Hariasih's research shows that partially motivation has a negative effect on work performance. [13]

The current phenomenon is that there are still many teachers who are not motivated to develop themselves. In addition, the lack of information on self-development for teachers in order to get achievements. There is still a lack of training or workshops for teachers in developing their potential to become quality educators. In addition, the principal has not been able to place teachers according to their talents and abilities. The principal must also be able to open two-way communication, and be able to delegate tasks to the right teacher. The principal is also expected to be able to improve the quality of teachers which in turn will improve the performance of the teachers themselves.

\section{Leadership}

According to the term leadership is the process of influencing individual or group activities to achieve certain goals in predetermined situations. In influencing their activities, individual leaders use power, authority, influence, characteristics and characteristics, and the goal is to increase the productivity and morale of the group.

According to Wahjosumidjo, several important things appear, namely: Leadership is seen as a series of processes or actions; There are goals to be achieved together; The leadership function is to influence, move others in activities or joint ventures; The activity or process leads to among several examples or guidance of organized activities or efforts; These activities take place in formal organizations; Leadership is also translated into terms: the characteristics of personal behaviour, influence on others, patterns of interaction, cooperative relationships between positions of an administrative position. [14]

Leadership in the field of education also means that leaders must have skills in influencing, encouraging, guiding, directing, and mobilizing other people who are related to the implementation and development of education and teaching or training so that all activities can run effectively and efficiently which in turn will achieve defined educational and teaching goals. [15]

Meanwhile, the principal can be defined as a functional teacher who is given the task of leading a school where the teaching and learning process is held or a place where there is interaction between the teacher who gives lessons and students who receive lessons. [16]

The term principal comes from the two words principal and school. Head can be interpreted as chairman or leader. Whereas school is defined as an institution in which there are teaching and learning activities. School is also a living environment after home, where the child lives for a few hours, where the child lives, which is generally at the stage of development, and educational institutions and places that serve to prepare children to face life. [17]

Leadership is often identified with authority, authority, dominating influence, and of course the material. Naturally, many people think leadership is only seen in terms of fun. And many people have ambitions for leadership, but few people actually live it effectively.

\section{Motivation}

The term motivation comes from the Latin word movere, which means "to move". According to McDonald, quoted by Hamalik. Motivation is a change in energy in a person's (personal) self which is marked by the emergence of feelings and reactions to achieve goals ". [18]. According to Hilgard, quoted by Sanjaya, namely "Motivation is a condition that exists in a person that causes a person to carry out certain activities to achieve certain goals". So work motivation is an encouragement that can cause someone to do activities or work to achieve goals. [19]

"Motivation stems from the word" motive "which means the driving force that is within a person to carry out certain activities in order to achieve a goal". [20] defines motivation as a condition that makes motives move according to the needs of each individual. [20]

According to Uno defines motivation as a force, both from within and from outside that encourages a person to achieve certain predetermined goals. [21] Meanwhile, Hasibuan stated that "Motivation is the giving of the driving force that creates the excitement of a person's work, so that they are willing to cooperate, work effectively and be integrated with all their efforts to achieve satisfaction." So motivation is what encourages someone to do something to achieve goals. [22]

Motivation is an important part of every activity, without motivation there is no real activity. Employees will work sincerely if they have high motivation. When employees have positive motivation, they will show interest, concern, and responsibility for their duties so that their performance increases. This is in line with Mulyasa's opinion that motivation is needed in activities that are directly related to improving performance. [23] 


\section{Achievement}

According to Ahmad Barizi and Muhammad Idris, teachers or educators act as guides in carrying out the teaching and learning process. Providing conditions that allow students to feel comfortable and confident that the skills and achievements achieved will receive appreciation and attention so that they can increase the achievement motivation of their students. [24] A narrower definition, namely, a teacher is a person whose job is to teach or provide lessons at school or in the classroom

Job performance is also called performance or performance. In principle, there is another term that describes achievement, namely the word "achievement" which means to achieve, so in Indonesian it is often interpreted as achievement or what is achieved.

According to Rivai, work performance is a translation of the word performance which comes from the word to perform with several entries, namely: 1) To do, carry out (to do or carry out, execute) 2) Fulfill or carry out an obligation of an intention or vows (to discharge of fulfil, as vow) 3) Carry out or perfect the responsibility (to execute or complete an understanding) 4) Do something that is expected by a person or machine (to do what is expected of a person machine) [3]

Performance is the result of work achieved by a person or group of people in an organization. Thus, the notion of work performance emphasizes more as a result or achievement achieved by someone in carrying out a job. [25]

M.As'ad states that work performance is the work success that someone gets from the deeds or results concerned. In line with Hasibuan (2005) states that work performance is a result of the work achieved by a person in carrying out the tasks assigned to him based on time, skill, seriousness and experience. [26]

In education management, the role of teachers in efforts to succeed in education is always to improve the performance or work performance of teachers must always be improved considering the challenges of the world of education to produce human resources who are able to compete in the global era

\section{METHODS}

This type of research is quantitative research, that is, according to [27] research that is focused on the study of objective phenomena to be studied quantitatively. Quantitative research is a process that uses data in the form of numbers as a tool to analyze information about what you want to know. This study uses a lot of numbers, ranging from data collection, interpretation of data and displaying research results. The data used in this study are primary data, namely questionnaire data obtained from interviews with wakasek teachers. This study consisted of two independent variables, namely teacher leadership (X1), teacher motivation (X2), while the dependent variable was teacher achievement $(\mathrm{Y})$.

The data collection research was conducted quantitatively. This research method uses partial and simultaneous regression methods, used for analysis or hypothesis testing if the researcher intends to determine the effect or relationship of the independent variable with the dependent, where one of the independent variables is controlled (made permanent) according to [28] ex post facto research design is research that aims to investigate events that have occurred and then according to backwardness to find out the factors that caused these events.

The population in this study were all educators at MTs Negeri 1 Musi Banyuasin, which consisted of 43 teachers. Sampling of this sample the researcher used a saturated sampling technique, namely a sampling technique that took the entire number of pupulations.

Data collection techniques in this study were carried out using questionnaires, interviews, observations or observations, exams or tests, documentation and so on. [29] Furthermore [20] that data collection techniques can be done by interview, questionnaire, observation, and a combination of the three. In this study, the data collection technique used by the researcher was a questionnaire that the respondent had to answer according to the situation he was experiencing, observation and documentation.

Data collected using a Likert scale model. The data analysis technique used simple regression analysis and multiple regression using SPSS For Windows version 25.00

\section{RESULTS AND DISCUSSION}

\section{The influence of leadership on teacher achievement}

The model of the leadership relationship to teacher achievement is expressed in the form of the regression equation $\mathrm{Y}=103.486+0.023 \mathrm{X} 1$. The regression equation significance test can be presented in the following table.

Table 1. The significance of leadership on teacher achievement

\begin{tabular}{|c|c|c|c|c|c|c|}
\hline \multirow[b]{2}{*}{ Model } & & \multicolumn{2}{|c|}{$\begin{array}{l}\text { Unstandardized } \\
\text { Coefficients }\end{array}$} & \multirow{2}{*}{$\begin{array}{l}\text { Standardize } \\
\text { d } \\
\text { Coefficients } \\
\text { Beta }\end{array}$} & \multirow[t]{2}{*}{$\mathrm{t}$} & \multirow[t]{2}{*}{ Sig. } \\
\hline & & B & $\begin{array}{l}\text { Std. } \\
\text { Error }\end{array}$ & & & \\
\hline \multirow[t]{2}{*}{1} & $\begin{array}{l}\text { (Constant } \\
\text { ) }\end{array}$ & $\begin{array}{l}103.48 \\
6\end{array}$ & $\begin{array}{l}13.93 \\
6\end{array}$ & & $\begin{array}{l}7.42 \\
6\end{array}$ & $\begin{array}{l}0.00 \\
0\end{array}$ \\
\hline & $\begin{array}{l}\text { leadershi } \\
\mathrm{p}\end{array}$ & -0.023 & 0.155 & -0.023 & $\begin{array}{l}- \\
0.14 \\
8\end{array}$ & $\begin{array}{l}0.88 \\
3\end{array}$ \\
\hline
\end{tabular}

Based on the significance test of the leadership variable on teacher achievement at MTs Negeri 1 Musi Banyuasin. obtained t value of -0.148 $<\mathrm{t}$ table price of 2.0166 where the $t$ value is smaller than $\mathrm{t}$ table and a significance value of 0.883 is 
greater than 0.05 , so Hol is rejected so that there is no significant influence between leadership on teacher achievement at MTs Negeri 1 Musi Banyuasin.

\section{The influence of teacher motivation on teacher achievement}

The model of the relationship between teacher motivation and teacher work performance is expressed in the form of the regression equation $\mathrm{Y}=$ $35.147+0.611 \mathrm{X} 2$. The significance test of the regression equation can be presented in the following table.

Table 2. The significance of teacher motivation on teacher performance

\begin{tabular}{|c|c|c|c|c|c|}
\hline \multirow[b]{2}{*}{ Model } & \multicolumn{2}{|c|}{$\begin{array}{l}\text { Unstandardized } \\
\text { Coefficients }\end{array}$} & \multicolumn{3}{|l|}{$\begin{array}{l}\text { Standardized } \\
\text { Coefficients }\end{array}$} \\
\hline & B & $\begin{array}{l}\text { Std. } \\
\text { Error }\end{array}$ & Beta & $\mathrm{t}$ & Sig. \\
\hline $1 \quad$ (Constant) & 35.147 & 18.287 & & 1.922 & 0.062 \\
\hline Motivation & 0.611 & 0.168 & 0.494 & 3.639 & 0.001 \\
\hline
\end{tabular}

Based on the significance test of the variable teacher motivation on teacher achievement at MTs Negeri 1 Musi Banyuasin. obtained t value of $3.639>t$ table price of 2.0166 where the value of $t$ is greater than t table and a significance value of 0.001 is less than 0.05 , so Ho1 is accepted so that there is a significant influence between teacher motivation on teacher achievement in MTs Negeri 1 Banyuasin Museum

The influence of leadership and teacher motivation on teacher achievement

The model of the relationship between leadership and teacher motivation to teacher achievement is expressed in the form of the regression equation $\mathrm{Y}=43,914+0.774 \times 1-297 \mathrm{X} 2$. This means that teacher achievement will experience a positive increase in teacher motivation and negative towards the leadership of the principal

Table 3. The significance of teacher leadership and motivation on teacher achievement

\begin{tabular}{llllll}
\hline & & $\begin{array}{l}\text { Unstandardized } \\
\text { Coefficients }\end{array}$ & $\begin{array}{l}\text { Standardized } \\
\text { Coefficients }\end{array}$ & & \\
\multicolumn{1}{l}{ Model } & $\mathrm{B}$ & Beta & $\mathrm{T}$ & Sig. \\
\hline $1 \quad$ (Constant) & 43.914 & & 2.424 & 0.020 \\
& Motivation & 0.774 & 0.626 & 4.298 & 0.000 \\
& Leadership & -0.297 & -0.299 & - & 0.047 \\
& & & 2.053 & \\
\hline
\end{tabular}

To find out the truth of hypothesis testing, a simultaneous test was carried out using the $\mathrm{F}$ test to determine the effect of leadership variables and teacher motivation on teacher achievement. The test criteria are as follows

a. If the probability value (significant) $<0.005$, then $\mathrm{Ho} 3$ is rejected

b. If the probability value (significant) $>0.005$, then $\mathrm{Ho} 3$ is accepted
Then for the F test, the test criteria are as follows

a. Ha3 is accepted if Fcount $>$ Ftable

b. H03 is accepted if Fcount $\leq$ Ftable.

The results of multiple regression analysis can be seen in the following table

Table. 4. The results of multiple regression analysis of leadership and teacher motivation towards achievement

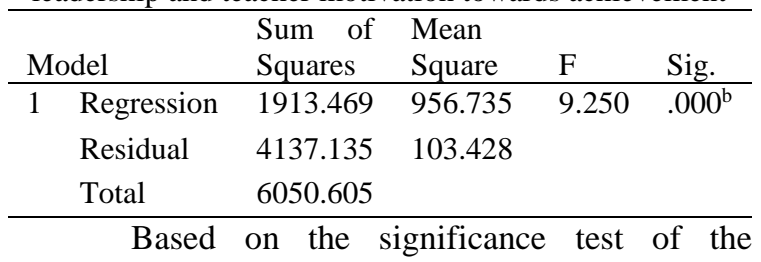
leadership variables and teacher motivation on the achievement of the MTs Negeri 1 Musi Banyuasin teacher together, the calculated $\mathrm{f}$ value is $9,250>$ the $\mathrm{f}$ table price is 3.23 where the calculated $\mathrm{f}$ value is greater than the $f$ table and the significance value is 0.001 which is smaller. from 0.005 then $\mathrm{Ho} 3$ is accepted so that there is a significant influence between leadership and teacher motivation on the achievement of the MTs Negeri 1 Musi Banyuasinteacher.To find out how much influence the independent variable has on the dependent variable in a simultaneous way can be seen in the following summary model table.

Table. 5. Summary model of leadership and motivation

\begin{tabular}{llllll}
\hline Model & $\mathrm{R}$ & R Square & $\begin{array}{l}\text { Adjusted } \\
\text { Square }\end{array}$ & $\mathrm{R}$ & $\begin{array}{l}\text { Std. Error of the } \\
\text { Estimate }\end{array}$ \\
\hline 1 & $.562^{\mathrm{a}}$ & 0.316 & 0.282 & 10.16997 &
\end{tabular}

The table above shows the $\mathrm{R}$ value which is a symbol of the correlation coefficient value. At the value above the correlation value is 0.562 This value can be interpreted that the relationship between the two research variables is in the strong category. Through this table also obtained the value of $R$ Square or the coefficient of determination (KD) which shows how good the regression model is formed by the interaction of the independent variables and the dependent variable. The value of $\mathrm{KD}$ obtained is 0.316 which can be interpreted that the independent variable $\mathrm{X}$ has a contribution effect of $31.6 \%$ on variable $\mathrm{Y}$ and 48.4 , the other\% is influenced by other factors outside variable $\mathrm{X}$

\section{Efforts to improve teacher achievement through increased leadership}

Based on observations in the field, most of the principal leadership uses a situational leadership style. Where the school principals see the conditions of their respective schools which are not the same as the desired conditions. This leadership style is used at MTs Negeri 1 Musi Banyuasin, the principal assigns some of his duties to his subordinates so that 
their subordinates know what happened and why it happened and what to do. The principal hopes that by giving them authority in accordance with the conditions in the school, teachers can feel transparent and eliminate distance from the leadership so that teachers concentrate on improving overall achievement.

Based on the description of the results of this study it has been proven that the principal leadership factor is a factor that has a positive influence on teacher work performance. This is in accordance with what Dharma argues that leadership is the process of influencing the activities of a person or group to achieve goals in certain situations. In this case, Dharma emphasizes that the key to leadership is the influence a person has and in turn the effect of that influence on the person who wants to be influenced. With the influence of the principal's leadership as a leader in the school environment, it will affect other work performance, especially teachers in carrying out their duties.

On the other hand, according to Dharma, leadership style is the behavior of the leader when he tries to influence the behavior of the people he leads. [30] The principal is the education leader in the school. If the notion of leadership is applied in educational organizations, educational leadership can be interpreted as an effort to mobilize people in educational organizations to achieve educational goals. Principals who have effective leadership must know, realize, and understand at least three things: "(1) why quality education is needed in schools; (2) what should be done to improve the quality and productivity of schools; and (3) how to manage the school effectively to achieve high achievement [1].

The existence of a leader is needed to coordinate all group activities of an organization and cannot be separated from his leadership style. Because the success or failure of an organization is felt to be very dependent on the leadership style of a leader.

Leadership plays a very important role in improving teacher work performance in carrying out assignments at school. The good and bad performance of teachers are influenced by the leadership of the principal. The better the principal applies leadership, the better the teacher's work performance. Conversely, the worse the principal applies leadership, the lower the teacher's work performance.

Leaders in schools who are successful in their leadership have a positive impact on teacher achievement in school. In line with Hasibuan, work performance is a result of work achieved by someone in carrying out the tasks assigned to him based on time, skill, seriousness and experience. [13]

The practical implication is that the principal as a new leader can see the conditions that develop in the school, see the situation, how and what to do for decision making. The leadership style of the principal who can see the conditions or situation will make the subordinates / teachers feel comfortable and do not seem authoritarian. If the teacher feels comfortable with the school leadership pattern, then it will indirectly improve teacher achievement.

This is in line with the research of [29] The Influence of Principal Leadership and School Committee Participation on Teacher Performance. The results showed that: (1) Principal leadership has a positive and significant effect on the performance of public high school teachers in the district. MuaraEnim. (2) School committee participation has a positive and significant effect on the performance of public high school teachers in MuaraEnim Regency, and (3) Principal leadership and school committee participation together have a positive and significant effect on the performance of public high school teachers in MuaraEnim Regency. [30]

In line with the research of [31] The Influence of Principal Leadership and Work Motivation on Teacher Performance. The results of the study state that 1) there is a significant influence between principal leadership on teacher performance; 2) there is a significant influence between work motivation on teacher performance, and 3) there is a significant influence jointly between principal leadership and work motivation on teacher performance. Keywords: Principal Leadership, Work Motivation, Teacher Performance [31]

This is in line with the research by [30] entitled The Influence of Principal's Leadership and Teacher's Competence toward Teacher's Performance in Indonesia. The results obtained in this study 1) there is no influence of principal leadership on teacher's performance; 2) there is an effect of teacher's competence on teacher's performance; and 3) there is simultaneously an effect of principal leadership and teacher's competence on teacher's performance. This paper contributes to improve teacher's performance through principal leadership and teacher's competence [31].

\section{Efforts to improve teacher performance through increasing teacher motivation}

Based on the results of field observations, the motivation of the teachers at MTs Negeri 1 Musi Banyuasin was not maximal, this was evident from their lack of enthusiasm to develop themselves. Teachers are still less interested in participating in various trainings and workshops held by Diknas. Teachers are still not brave enough to improvise in teaching and learning activities.

In this study, teacher motivation at MTs Negeri 1 Musi Banyuasin had no and no significant effect on teacher work performance. The high level of motivation has no effect on achievement, likewise the low level of teacher morale will not affect the work performance of teachers in school 
A person's work performance can be said to be high if a work target can be completed at the right time or does not exceed the limit provided. A person's work performance can be said to be low if it is completed beyond the specified time limit or is not completed at all.

Motivation can serve as a driving force for business and achievement. Someone does an effort because of motivation. The existence of good motivation in learning will show good results. In other words, with diligent effort and primarily based on motivation, someone who learns will be able to produce good achievements. [25]

The practical implication is that with the motivation of the teachers at MTs Negeri 1 Musi Banyuasin in carrying out the teaching and learning process activities, this strong enthusiasm and encouragement will improve the achievement of the teachers themselves. So it is hoped that all teachers at MTs Negeri 1 Musi Banyuasin are always highly motivated in their lives.

This is in line with the research of TitinDamayani, Yasir Arafat, Syaiful Eddy. 2017 entitled The Influence of Principal Leadership and Work Motivation on Teacher Performance. The results of the study stated that 1) there was a significant influence between the principal's leadership on teacher performance; 2) there is a significant influence between work motivation on teacher performance; and 3) there is a significant influence jointly between principal leadership and work motivation on teacher performance. Keywords: Principal Leadership, Work Motivation, Teacher Performance [32]

Wahidy's 2010 research entitled The Role of Parents and Teachers Fostering Student Motivation. The Role of Parents and Teachers Fostering Student Motivation. The position and function of parents and teachers are some of the factors that determine the growth of student motivation to learn. Cooperation between parents and teachers is one of the most important indicators that can be done to foster student motivation in learning. [33]

\section{Efforts to improve teacher achievement through increased leadership and teacher motivation}

Leaders must understand the character of each employee. Understanding the character of employees is the first step to jointly advance the company. By knowing the characteristics of each employee, the treatment that the leadership can do is in accordance with what is expected,

Leaders can also provide compensation in the form of prizes for employees who have done a good job. This is to motivate and encourage employees to continue to work well, so that employee performance will continue to increase. Employees who are thirsty for knowledge, leaders can provide appropriate direction to improve abilities.
The factors of work (external) include: salary received, school policies, supervision, human relations, working conditions, organizational culture, recognition of achievement, level or amount of responsibility given, satisfaction from work. All of these factors will have a major influence on the achievement of a teacher, with high motivation it is hoped that the teacher will perform better for himself and the school where the teacher serves.

According to [30] states that work performance is the work success that someone gets from the deeds or results concerned. In line with [34] states that work performance is the result of work achieved by a person in carrying out the tasks assigned to him based on time, skill, seriousness and experience.

This is in line with the research of [34] with the title The Effect of Principal Leadership Style and Interpersonal Communication on Teacher Performance. The results showed: (1) the principal's leadership style had a significant effect on teacher performance 3) the principal's leadership style and interpersonal communication had a significant effect on teacher performance. [34]

The desire for achievement must always be instilled in the entire community of MTs Negeri 1 Musi Banyuasin. Because increasing the desire to always excel will give a strong spirit to build schools, indirectly improving the quality of teachers, students, and the school as a whole.

\section{CONCLUSION}

Based on the results of data analysis, the influence of principal leadership and teacher motivation both partially and simultaneously on teacher work performance can be explained as follows: Based on the results of the partial test below, it can be seen that the variable of school principal leadership has a $t$ value greater than $f$ table. This shows that leadership has a partial and insignificant effect on teacher achievement. Based on the results of partial testing in the table below, it can be seen that the work motivation variable has a $t$ value greater than $\mathrm{t}$ table. This shows that motivation partially and significantly influences teacher achievement. Based on the test results in the table above, it can be seen that the variables of principal leadership and teacher motivation have an $\mathrm{f}$ value of the $\mathrm{f}$ table. This shows that the principal's leadership and teacher motivation simultaneously and significantly influence teacher achievement.

\section{REFERENCES}

[1] Romlah, O. Y., \& Latief, S. (2021). Empowering the Quality of School Resources in Improving the Quality of Education. Bulletin of Science Education, 1(1), 37-41..

[2] Ramadina, E. (2021). Aktualisasi Supervisi Artistik dalam Manajemen Pendidikan Islam. 
Attractive: Innovative Education Journal, 3(1), 91-101.

[3] Suhono, S., \& Sari, D. A. (2020). Developing Students' Worksheet Based Educational Comic for Eleventh Grade of Vocational High School Agriculture. Anglophile Journal, 1(1), 29-40.

[4] Annur, S., \& Suhono, S. (2019). Implementasi manajemen pergruruan tinggi (studi kasus pada ptkis kopertais wilayah vii sumatera selatan). JMKSP (Jurnal Manajemen, Kepemimpinan, dan Supervisi Pendidikan), 4(1), 67-75.

[5] Salifu, I., \& Agbenyega, J. S. (2013). Teacher motivation and identity formation: Issues affecting professional practice. MIER Journal of Educational Studies Trends \& Practices, 5874.

[6] Tengko, F., Limbong, M., \& Kailola, L. G. (2021). Pengaruh Supervisi Akademik Pengawas Sekolah Terhadap Kinerja Guru SMP di Kecamatan Tondon Kabupaten Toraja Utara. Attractive: Innovative Education Journal, 3(1), 13-23.

[7] Mulyasa, Kurikulum Berbasis Kompetensi: Konsep, Karakteristik, Implementasi, dan Inovasi. Bandung: Remaja Rosdakarya, 2007.

[8] Sarni, S., \& Muslimah, M. (2021). The Commendable Leadership in Islamic Perspective. Bulletin of Pedagogical Research, 1(1), 163-173.

[9] E. Sutrisno, Manajemen Sumber Daya Manusia. Jakarta.: Kencana Prenada Media Group, 2014.

[10] V. Rivai, Manajemen Sumber Daya Manusia Untuk Perusahaan, Cetakan Pe. Jakarta.: Raja Grafindo Persada, 2004.

[11] Sutikno, Belajar dan Pembelajaran. Bandung: Prospect, 2009.

[12] R. A. Hidayat, Subuh dan Sari, "Pengaruh Motivasi Kerja Dan Kompetensi Terhadap Prestasi Kerja Guru Di Sma Negeri 08 Kota Lubuklinggau.," J. Media Ekon., vol. 22, no. 2, 2017.

[13] Fahmi, Amirul dan Misti Hariasih, "Pengaruh Motivasi, Pengalaman Kerja Dan Lingkungan Kerja Terhadap Prestasi Kerja Guru SMK Muhammadiyah 1 Ngoro Jombang," J. Bisnis, Manaj. Perbank., vol. 2, no. 2, pp. 121-140, 2016.

[14] Wahjosumidjo, Kepemimpinan Kepala Sekolah tinjauan teoritik dan permasalahan. Jakarta.: PT Raja Grafindo Persada, 2002.

[15] Sulistyorini, "Hubungan Antara Manajerial Kepala Sekolah Dan Iklim Organisasi Dengan Kinerja Guru," J. Ilmum Pendidik., vol. 8, no. 2, p. 63, 2008 .

[16] O. Hamalik, Kurikulum dan Pembelajaran. Jakarta.: Bumi Aksara, 2011.

[17] W. Sanjaya, Strategi pembelajaran berorientasi standar proses pendidikan. Jakarta.: Kencana Prenada Media Group, 2006.
[18] Sardiman., Interaksi dan motivasi belajar Mengajar. Jakarta.: Raja Grafindo Persada, 2011.

[19] Uno, Hamzah B. \& Nina Lamatenggo., Teori Kinerja dan Pengukurannya. Jakarta.: Bumi Aksara, 2012.

[20] Hasibuan, H. Malayu, S.P, Manajemen Sumber Daya Manusia, Ke tiga. Jakarta.: Bumi Aksara, 2015.

[21] A. M. I. Barizi, Menjadi Guru Unggul. Yogyakarta: Ar-Ruzz, 2010.

[22] Prawirosentono., Manajemen Sumber Daya Manusia Kebijakan Kinerja Karyawan. Yogyakarta: BPFE Yogyakarta, 2009.

[23] As'ad., Seri ilmu sumber daya manusia: Psikologi industri. Jakarta.: Penerbit Liberty, 2015.

[24] H. M. Musfiqon, Metodologi Penelitian Pendidikan. Jakarta.: PT Prestasi Pustakaraya, 2012.

[25] Sugiyono, Metode Penelitian Kuantitatif dan $R$ dan D. Bandung: Alfabeta, 2013.

[26] Arikunto, . Prosedur Penelitian Suatu Pendekatan Praktek. Jakarta.: Rineka Cipta, 2010.

[27] Sugiyono., Metode Penelitian Pendidikan: Pendekatan Kuantitatif, Kualitatif, dan $R \& D$. Bandung: Alfabeta, 2012.

[28] A. Dharma, ). Manajemen Prestasi Kerja. Jakarta.: Rajawali Press, 2000.

[29] Imansyah Yasir Arafat,, Dessy Wardiah, "Pengaruh Kepemimpinan Kepala Sekolah Dan Partisipasi Komite Sekolah Terhadap Kinerja Guru," JMKSP (Jurnal Manajemen, Kepemimpinan, dan Supervisi Pendidikan), vol. 5, no. 2, p. 135, 2020, doi: 10.31851/jmksp.v5i2.3756.

[30] Titin Damayani, Yasir Arafat, Syaiful Eddy., "Pengaruh Kepemimpinan Kepala Sekolah Dan Motivasi Kerja Terhadap Kinerja Guru," J. Adm. Pendidik. Progr. Pascasarj. Unsyiah, vol. 5, no. 3, pp. 46-57, 2017.

[31] Suratman, Yasir Arafat, Syaiful Eddy., "The Influence of Principal $\mathrm{s}$ Leadership and Teacher 's Competence toward Teacher' $s$ Performance in Indonesia," vol. 1, no. 20, pp. 96-104, 2020.

[32] Sadiman, Media Pendidikan, Pengertian, Pengembangan dan Pemanfaatannya. Jakarta.: Raja Grafindo Persada, 2008.

[33] A. Wahidy, "Peran orang tua dan guru menumbuhkan motivasi belajar siswa," no. April, pp. 1-17, 2010.

[34] Kartini, Syarwani Ahmad, Syaiful Eddy., "Pengaruh Gaya Kepemimpinan Kepala Sekolah dan Komunikasi Interpersonal Terhadap Kinerja Guru," J. Educ. Res., vol. 1, no. 3, pp. 290-294, 2020, doi: 10.33753/mandiri.v3i2.85. 